\title{
Impact of phosphorus and potassium levels on yield and yield components of maize
}

Gul Sadiq ${ }^{1}$, Asad Ali Khan ${ }^{1}$, Inamullah ${ }^{1}$, Abdul Rab ${ }^{1 *}$, Hina Fayyaz ${ }^{2}$, Gul Naz ${ }^{1}$, Haq Nawaz ${ }^{1}$, Izhar Ali ${ }^{1}$, Haneef Raza ${ }^{3}$, Jalal Amin ${ }^{4}$, Shahid Ali $^{3}$, Haider Ali Khan ${ }^{1}$, Aamir Ali Khan ${ }^{1}$ and Wajid Ali Khattak ${ }^{1}$

1. Department of Agronomy, University of Agriculture Peshawar-Pakistan

2. Directorate General Agricultural Research Peshawar, Khyber Pakhtunkhwa-Pakistan

3. Department of Agriculture, University of Swabi-Pakistan

4. Department of Horticulture, University of Agriculture Peshawar-Pakistan

*Corresponding author's email: abdulrab@aup.edu.pk

Citation

Gul Sadiq, Asad Ali Khan, Inamullah, Abdul Rab, Hina Fayyaz, Gul Naz, Haq Nawaz, Izhar Ali, Haneef Raza, Jalal Amin, Shahid Ali, Haider Ali Khan, Aamir Ali Khan and Wajid Ali Khattak. Impact of phosphorus and potassium levels on yield and yield components of maize. Pure and Applied Biology. . Vol. 6, Issue 3, pp1071-1078. http://dx.doi.org/10.19045/bspab.2017.600114

Received: 15/05/2017 Revised: 22/08/2017

Accepted: 26/08/2017

Online First: 05/09/2017

\section{Abstract}

Intensive cropping pattern has deprived the soil of essential plant nutrients such as nitrogen $(\mathrm{N})$, phosphorus $(\mathrm{P})$ and potassium $(\mathrm{K})$. This has resulted in lowering maize yield. $\mathrm{P}$ application control plant growth behavior. $\mathrm{P}$ is needed for utilization of sugar and starch, photosynthesis, cell division, nucleus and fat and albumen formation. $\mathrm{K}$ is well documented in protein synthesis, enzyme activation, stomatal movement, water relation and photosynthesis in plants. The aim of this study was to evaluate the impact of $\mathrm{P}$ and $\mathrm{K}$ on yield and yield components of maize. The experiment was carried out in randomized complete block design during 2014-15 at Agronomy Research Farm of Agriculture University Peshawar-Pakistan. Maize hybrid "Pioneer-3025" was use as a test crop. Experiment was composed of four levels of P $\left(0,60,90\right.$ and $\left.120 \mathrm{~kg} \mathrm{ha}^{-1}\right)$ and four level of $\mathrm{K}\left(0,60,90\right.$ and $\left.120 \mathrm{~kg} \mathrm{ha}^{-1}\right)$. Result showed that $\mathrm{P}$ applied at $120 \mathrm{~kg} \mathrm{ha}^{-1}$ increased rows ear ${ }^{-1}$ by $40 \%$, grains row $^{-1}$ by $18 \%$, grains ear ${ }^{-1}$ by $41 \%$, thousand grains weight by $8 \%$, biological yield by $41 \%$, stover yield by $34 \%$, grain yield by $55 \%$ and harvest index by $10 \%$ over control. Similarly, K applied at $90 \mathrm{~kg} \mathrm{ha}^{-1}$ increased rows ear ${ }^{-1}$ by $40 \%$, grains row $^{-1}$ by $15 \%$, grains ear $^{-1}$ by $36 \%$, thousand grains weight by $8 \%$, biological yield by $36 \%$, stover yield by $25 \%$, grain yield by $56 \%$ and harvest index by $15 \%$ over control. It is concluded that $\mathrm{P}$ at the rate of $120 \mathrm{~kg} \mathrm{ha}^{-1}$ and $\mathrm{K}$ at the rate of $90 \mathrm{~kg} \mathrm{ha}^{-1}$ should be applied for improved yield and yield component of maize in agro climatic conditions of Peshawar.

Keywords: Maize; Phosphorus; Potassium; Yield; Yield components; Levels

\section{Introduction}

In Pakistan maize (Zea mays L.) is grown as an important kharif (summer) cereal [1]. Being an imperative crop following wheat and rice it is utilized as cooking oil for human and feed for livestock. Alcoholic and non-alcohol drinks, fuel and medicines are produced from maize. It is used for the 
preparation of liquid glucose, dextrin, powder glucose, crystalline dextrose and solid glucose. Maize grain has $10 \%$ protein, $77 \%$ starch, $5.8 \%$ fiber, $4.8 \%$ oil, and $3.0 \%$ sugar. It is used for preparation of corn flakes, tanning materials, cosmetics and wax [2]. During 2013-14 in Pakistan, the total area under maize cultivation was 1169 thousand hectares with production of 5044 thousand tons and average yield of $4317 \mathrm{~kg}$ ha $^{-1}$. Whereas, in Khyber Pakhtunkhwa the figures were 471 thousand hectares with production of 915 thousand tons and average yield of $1943 \mathrm{~kg} \mathrm{ha}^{-1}$ in the same year [3]. Maize being an exhaustive crop has high potential than other cereal crops and absorbs huge amount of nutrients during the growth stage from soil. Phosphorus is the second most crops limiting in most of soils [4]. It is essential for growth, consumption of starch and sugar, nucleus formation, photosynthesis, cell division and fat formation [4]. Phosphate compounds store energy from the metabolism of carbohydrates and photosynthesis for later growth of crop [5]. Phosphorus is mobile in plant which moves form older to younger tissues during the development of root, stem and leaves [6]. Application of $\mathrm{P}$ in sufficient quantity improves quality of vegetative growth and results in rapid growth and earlier maturity. About $90 \%$ of Pakistani soil is $\mathrm{P}$ deficient and its deficiency resulted in crooked and missing rows as kernel twist and produced small nubbies in maize [1]. $\mathrm{P}$ at the rate of $150 \mathrm{~kg} \mathrm{ha}^{-1}$ more gave more ears plant ${ }^{-1}(13 \%), 1000$ grains weight $(12 \%)$ and grain yield (30\%) over control plots [7].

Potassium (K) being an important macronutrient is a primary osmoticum in maintaining low water potential in plant tissues. It plays a vital role in protein synthesis, enzyme activation, photosynthesis, regulation of plant stomata, translocation of photosynthates and many other processes [8]. It improves the soil physical properties known as soil aggregating agent. $\mathrm{K}$ cations are present in plants in large amount and play an essential role in several biochemical and physiological processes. $\mathrm{K}$ has a vital role to withstand the plant during water shortage [9]. Keeping in view the importance of $P$ and $\mathrm{K}$ and their synergistic effect the present study was aimed at evaluating the impact of phosphorus and potash level on yield and yield component of maize in agro climatic conditions of Peshawar valley.

\section{Materials and methods}

A field trail was conducted to evaluate the impact of phosphorus and potassium levels on yield and yield components of maize at Agronomy Research Farm, Agriculture University Peshawar-Pakistan during 201415. The experiment was carried out in randomized complete block design having four replications. A plot size of $10.5 \mathrm{~m}^{2}$ having $3.5 \mathrm{~m}$ width and $3 \mathrm{~m}$ length was used. Each plot had five rows. Row to row distance was $70 \mathrm{~cm}$ and plant to plant distance was $20 \mathrm{~cm}$. The experiment was composed of four levels of phosphorus $(0$, 60,90 and $120 \mathrm{~kg} \mathrm{ha}^{-1}$ ) and four level of potassium (0, 60, 90 and $\left.120 \mathrm{~kg} \mathrm{ha}^{-1}\right)$. Phosphorus as single super phosphate and potassium as sulphate of potash was applied at sowing time. Nitrogen at the rate of 150 $\mathrm{kg} \mathrm{ha}{ }^{-1}$ was treated in spilt doses half at sowing time and half at second irrigation at V3 (third leaf) stage. Maize hybrid "Pioneer-3025" was use as test crop. The crop was cultivated on $19^{\text {th }}$ June, 2014 and harvested on $10^{\text {th }}$ October, 2015. All recommended agronomic practices (weeding, hoeing, pesticides, irrigation etc.) were kept uniform for all the treatment and were carried out throughout the growing season, when required.

\section{Data Measurements}

During the experiment data were recorded using the standard procedure for each 
parameter. Data on rows ear ${ }^{-1}$ was calculated by selecting ears randomly from each plot after harvesting. Rows were counted in each ear and then were averaged. Three ears rows were selected at random for grains row $^{-1}$ data from each plot after harvesting, and the number of grains row $^{-1}$ were counted and then averaged. Data regarding grains number ear ${ }^{-1}$ was recorded by selecting five ears at random from each experimental unit.
Ears were dried and shelled. Grains were counted in each ear and then averaged.1000 grains were counted at random from each experimental unit and weighed with electronic weighing scale. Biological yield was recorded by collecting dried harvested plants of three center rows from each plots and weighed with spring balance. Biological yield in $\mathrm{kg} \mathrm{ha}^{-1}$ was recorded using the given equation.

\section{Biological yield $\left(\mathrm{kg} \mathrm{ha}^{-1}\right)=\frac{\text { Central three rows biomass yield }(\mathrm{kg})}{\text { No of Rows x Row length } \mathrm{x} \text { Row to row distance }} \times 10000$}

After shelling sun dried ears of three central rows was weighed from each experimental unit. Grain yield in $\mathrm{kg} \mathrm{ha}^{-1}$ was recorded using the given equation.

\section{Grain yield $\left(\mathrm{kg} \mathrm{ha}^{-1}\right)=\frac{\text { Central three rows grain yield }(\mathrm{kg})}{\text { No of Rows } \mathrm{x} \text { Row length } \mathrm{x} \text { Row to row distance }} \times 10000$}

After harvesting stover yield was measured on the following formula:

Stover yield $=$ Biological yield - Grain yield Harvest index (H.I) in percentage was determined as under.

H.I = Economic yield/Biological yield x 100 Statistical analysis

Analysis of variance was carried out to verify the significance influence of the treatments under RCBD using LSD (least significant difference) test for the mean comparison where treatment and its interaction found significant [10].

\section{Results and discussion}

\section{Rows ear-1}

Phosphorus (P) and potassium (K) levels significantly influenced row ear $^{-1}$ of maize, whereas $\mathrm{P} \quad \mathrm{X} \quad \mathrm{K}$ interaction was nonsignificant (Table 1). Mean values for $\mathrm{P}$ showed that more rows ear ${ }^{-1}$ (14) were recorded with $120 \mathrm{~kg} \mathrm{P}^{-1}$, whereas less rows ear $^{-1}$ (10) were noted in control plots. More rows ear ${ }^{-1}$ with higher rate of $\mathrm{P}$ might be due to the positive response of $\mathrm{P}$ for rapid growth. Our results are in line with $[6,11]$ who reported more rows ear $^{-1}$ with increase in $\mathrm{P}$ rate. Mean values for $\mathrm{K}$ showed that more rows ear ${ }^{-1}$ (14) were noted when $\mathrm{K}$ was applied with $120 \mathrm{~kg} \mathrm{ha}{ }^{-1}$ which was statistically at par with K applied with $90 \mathrm{~kg}$ $\mathrm{ha}^{-1}$ resulting in 13 rows ear $^{-1}$, whereas control plots gave less rows ear ${ }^{-1}$ (10). Increase in rows ear $^{-1}$ with increase in $\mathrm{K}$ level might be due to more translocation of photosynthates to ear which resulted in more rows ear ${ }^{-1}[12]$. Similar results were noted by [13-15] who reported that $\mathrm{K}$ application increased the number of grain rows $\mathrm{cob}^{-1}$.

\section{Grains row ${ }^{-1}$}

$\mathrm{P}$ and $\mathrm{K}$ levels significantly influenced grains row $^{-1}$ of maize, whereas $\mathrm{P} \times \mathrm{K}$ interaction was non-significant (Table 1). $\mathrm{P}$ mean values showed that $\mathrm{P}$ applied at the rate of $120 \mathrm{~kg} \mathrm{ha}^{-1}$ gave higher grains row ${ }^{-1}$ (39), whereas lower grains row ${ }^{-1}$ were recorded in control plots. These results are confirmed by [16-17] who reported more grains row $^{-1}$ with higher level of P. Mean values for $\mathrm{K}$ showed that higher grains row $^{-1}$ (38) were resulted with those plots where $120 \mathrm{~kg} \mathrm{~K} \mathrm{ha}^{-1}$ was applied, which was statistically at part when $90 \mathrm{~kg} \mathrm{~K} \mathrm{ha}^{-1}$ was applied, which resulted in (37) grains row ${ }^{-1}$ 
of maize, whereas lower grains row $^{-1}$ (33) were noted in control plots.

Table 1. Mean values for rows ear-1, grains row $^{-1}$, grains ear ${ }^{-1}$, thousand grain weight (TGW), biological yield (BY), grain yield (GY), stover yield (SY) and harvest index (HI) of maize as influenced by phosphorus and potassium levels.

\begin{tabular}{|c|c|c|c|c|c|c|c|c|}
\hline Treatment & $\begin{array}{l}\text { Rows } \\
\text { ear }^{-1}\end{array}$ & $\begin{array}{c}\text { Grains } \\
\text { row }^{-1}\end{array}$ & $\begin{array}{c}\text { Grains } \\
\text { ear }^{-1}\end{array}$ & $\begin{array}{c}\text { TGW } \\
\text { (g) }\end{array}$ & $\begin{array}{c}\text { BY } \\
\left(\mathrm{kg} \mathrm{ha}^{-1}\right)\end{array}$ & $\begin{array}{c}\text { GY } \\
\left(\mathrm{kg} \mathrm{ha}^{-1}\right)\end{array}$ & $\begin{array}{c}\text { SY } \\
\left(\mathrm{kg} \mathrm{ha}^{-1}\right)\end{array}$ & $\begin{array}{c}\text { HI } \\
(\%)\end{array}$ \\
\hline \multicolumn{9}{|c|}{ Phosphorus level $\left(\mathrm{kg} \mathrm{ha}^{-\mathbf{1}}\right)$} \\
\hline 0 & $10 \mathrm{c}$ & $33 \mathrm{c}$ & $357 \mathrm{c}$ & $294 \mathrm{c}$ & $9241 \mathrm{~d}$ & $3160 \mathrm{~d}$ & $6081 \mathrm{~d}$ & $34.0 \mathrm{~b}$ \\
\hline 60 & $12 \mathrm{~b}$ & $36 \mathrm{~b}$ & $420 \mathrm{~b}$ & $305 \mathrm{~b}$ & $11034 \mathrm{c}$ & $4164 \mathrm{c}$ & $6869 \mathrm{c}$ & $37.6 \mathrm{a}$ \\
\hline 90 & $12 \mathrm{~b}$ & $36 \mathrm{~b}$ & $438 \mathrm{~b}$ & $307 \mathrm{~b}$ & $12041 \mathrm{~b}$ & $4532 \mathrm{~b}$ & $7508 \mathrm{~b}$ & $37.4 \mathrm{a}$ \\
\hline 120 & $14 \mathrm{a}$ & $39 a$ & $503 \mathrm{a}$ & $317 \mathrm{a}$ & $13006 \mathrm{a}$ & $4883 \mathrm{a}$ & $8124 \mathrm{a}$ & $37.4 \mathrm{a}$ \\
\hline $\operatorname{LSD}_{(0.05)}$ & 0.8 & 2.0 & 41.4 & 9.1 & 118.4 & 132.1 & 171.0 & 1.2 \\
\hline \multicolumn{9}{|c|}{ Potassium levels $\left(\mathrm{kg} \mathrm{ha}^{-1}\right)$} \\
\hline 0 & $10 \mathrm{c}$ & $33 \mathrm{c}$ & $353 \mathrm{c}$ & $293 \mathrm{c}$ & $9151 \mathrm{c}$ & $3046 \mathrm{c}$ & $6105 \mathrm{c}$ & $33.1 \mathrm{~b}$ \\
\hline 60 & $12 \mathrm{~b}$ & $35 \mathrm{~b}$ & $417 \mathrm{~b}$ & $303 \mathrm{~b}$ & $11427 \mathrm{~b}$ & $4278 \mathrm{~b}$ & $7149 \mathrm{~b}$ & $37.4 \mathrm{a}$ \\
\hline 90 & $12 \mathrm{~b}$ & $37 \mathrm{ab}$ & $469 \mathrm{a}$ & $311 \mathrm{ab}$ & $12322 \mathrm{a}$ & $4654 \mathrm{a}$ & $7668 \mathrm{a}$ & $37.6 \mathrm{a}$ \\
\hline 120 & $14 \mathrm{c}$ & $38 \mathrm{a}$ & $479 \mathrm{a}$ & $315 \mathrm{a}$ & $12422 \mathrm{a}$ & $4762 \mathrm{a}$ & $7660 \mathrm{a}$ & $38.2 \mathrm{a}$ \\
\hline $\operatorname{LSD}_{(0.05)}$ & 0.8 & 2.0 & 41.4 & 9.1 & 118.4 & 132.1 & 171.0 & 1.2 \\
\hline \multicolumn{9}{|c|}{ Interactions } \\
\hline $\mathrm{P} \times \mathrm{K}$ & NS & NS & NS & NS & $* *$ & $* *$ & $* *$ & $\mathrm{NS}$ \\
\hline
\end{tabular}

Means of the same category followed by different letter (s) are significantly different at $\mathrm{P} \leq 0.05$ level using LSD test. NS $=$ Non-Significant, $* *$ Significant at $\mathrm{P} \leq 0.01$ level using LSD test

\section{Grains ear ${ }^{-1}$}

$\mathrm{P}$ and potash $\mathrm{K}$ levels significantly influenced grains ear ${ }^{-1}$ of maize, whereas $\mathrm{P} x$ $\mathrm{K}$ interaction was non significant (Table 1). Mean value for $\mathrm{P}$ showed that more grains ear $^{-1}$ (503) were recorded when $\mathrm{P}$ levels was applied at the rate of $120 \mathrm{~kg} \mathrm{ha}^{-1}$ whereas, less grains ear-1 (436) were noted in control plots. Our results are in line with [18-20] who reported that grains ear ${ }^{-1}$ were enhanced with increased in P level. Mean values for $\mathrm{K}$ levels indicated that maximum grains ear $^{-1}$ (497) was recorded in plots where potash was applied at the rate of $120 \mathrm{~kg} \mathrm{ha}^{-1}$ though statistically similar to plots where potash was applied at the rate of $90 \mathrm{~kg} \mathrm{ha}^{-1}$ (497) while minimum grains ear $^{-1}$ (431) was obtained in control plots. The reasons for maximum grain ear ${ }^{-1}$ could be attributed to the maximum availability of potash which resulted in increased photosynthetic activities, which resulted in more translocation of food materials to the grain [21-22] also reported that maize produced maximum number of grains ear ${ }^{-1}$ with increased in $\mathrm{K}$ level.

\section{Thousand grains weight (g)}

$\mathrm{P}$ and $\mathrm{K}$ levels significantly influenced thousand grains weight of maize, whereas $\mathrm{P}$ $\mathrm{x} \mathrm{K}$ interaction was non significant (Table 1). Thousand grains weight increased with increase in $\mathrm{P}$ and $\mathrm{K}$ levels. Mean values for $\mathrm{P}$ showed that more thousand grains weight (317 g) was recorded in plots where $\mathrm{P}$ was applied at the rate of $120 \mathrm{~kg} \mathrm{ha}^{-1}$ whereas, minimum thousand grains weight (294 g) was recorded in those plots where no $\mathrm{P}$ was applied. Increase in thousand grains weight may be due to more assimilates transferred to grains. Similar results were reported by [23]. Mean value for $\mathrm{K}$ levels showed that increased thousand grains weight (315 g) was recorded in plots where $\mathrm{K}$ was applied at the rate of $120 \mathrm{~kg} \mathrm{ha}^{-1}$ whereas, minimum 
thousand grains weight (293 g) was recorded in control plots. This might be due to the increased translocation of assimilates from leaf to grain [24] who recorded that $K$ increase enzymes activities in the plant which is important for accumulation and translocation of assimilates from leaf to grain that resulted increased grain weight.

\section{Biological yield ( $\mathrm{kg} \mathrm{ha}^{-1}$ )}

$\mathrm{P}$ and $\mathrm{K}$ levels and $\mathrm{P} \times \mathrm{K}$ interaction significantly influenced biological yield of maize (Table 1). Biological yield increased with increase in $\mathrm{P}$ and $\mathrm{K}$ levels. Mean values for $\mathrm{P}$ showed that maximum biological yield (13006 $\mathrm{kg} \mathrm{ha}^{-1}$ ) was recorded in plots where $\mathrm{P}$ was applied at the rate of $120 \mathrm{~kg} \mathrm{ha}^{-1}$, while minimum biological yield $(9241 \mathrm{~kg}$ $\mathrm{ha}^{-1}$ ) was recorded in control plots. The possible reason for increased in biological yield with high $P$ level could be that adequate supply of $\mathrm{P}$ to plants increase root growth which explore the plant most soil moisture and nutrients. Another possible reason could be the well photosynthesis and other physiological functions of the plant [25]. Mean values for $\mathrm{K}$ showed that $\mathrm{K}$ application at the rate of $120 \mathrm{~kg} \mathrm{ha}^{-1}$ produced more biological yield $(12422 \mathrm{~kg}$ $\left.\mathrm{ha}^{-1}\right)$, whereas control plots resulted minimum biological yield (9151 $\left.\mathrm{kg} \mathrm{ha}^{-1}\right)$. P and $\mathrm{K}$ interaction indicated that more biological yield was resulted when $\mathrm{P}$ and $\mathrm{K}$ were applied at the rate of $120 \mathrm{~kg} \mathrm{ha}^{-1}$ each. It may be due to the increase of potash increased $\mathrm{CO}_{2}$ assimilation rate, enzyme activity, stomata closure and stabilized osmosis regulation which produced more carbohydrates which improved grain yield and biological yield, as recorded by [26-27].

\section{Grain yield ( $\mathrm{kg} \mathrm{ha}^{-1}$ )}

$\mathrm{P}$ and $\mathrm{K}$ levels and $\mathrm{P} \times \mathrm{K}$ interaction significantly influenced grain yield of maize (Table 1). Mean values for $\mathrm{P}$ showed that more grain yield (4883 $\left.\mathrm{kg} \mathrm{ha}^{-1}\right)$ was noted in those plots where $120 \mathrm{~kg} \mathrm{P} \mathrm{ha}^{-1}$ was applied whereas, minimum grain yield $\left(3160 \mathrm{~kg} \mathrm{ha}^{-}\right.$
1) was recorded in control plots. Our results are in line with those of [28] who reported more grain yield with higher rate of $\mathrm{P}$ applied. Mean values for $\mathrm{K}$ indicated that higher grain yield (4762 $\mathrm{kg} \mathrm{ha}^{-1}$ ) was recorded in those plots where $\mathrm{K}$ was applied at the rate of $120 \mathrm{~kg} \mathrm{ha}^{-1}$ though statistically similar with $90 \mathrm{~kg} \mathrm{~K} \mathrm{ha-1}$ (4654) while minimum grain yield (3046) was recorded in control plots. The increase in grain yield might be due to maximum utilization of $\mathrm{K}$ by maize that increased grains ear ${ }^{-1}$, grains weight and hence grain yield. Our results are in line with [29-31] who reported that grain yield increased with the increase in $\mathrm{K}$ level. $\mathrm{P} \times \mathrm{K}$ interaction significantly affected grain yield. Increasing the level of both nutrients resulted in increase grain yield. Our findings are similar with those of $[6,20,32-33]$ who reported more grain yield with $\mathrm{P}$ and $\mathrm{K}$ application.

\section{Stover yield (kg ha-1)}

$\mathrm{P}$ and $\mathrm{K}$ levels and $\mathrm{P} \times \mathrm{K}$ interaction significantly influenced stover yield of maize (Table 1). Mean values for $\mathrm{P}$ showed that $120 \mathrm{~kg} \mathrm{P} \mathrm{ha}^{-1}$ application gave more stover yield (8124 $\left.\mathrm{kg} \mathrm{ha}^{-1}\right)$ whereas, control plots resulted in lower stover yield $(6081 \mathrm{~kg}$ $\left.\mathrm{ha}^{-1}\right)$. Increased in stover yield at higher $\mathrm{P}$ level indicated that applying more $\mathrm{P}$ increased availability of $\mathrm{P}$. Khyber Pakhtunkhwa soil have high fixation capacity with higher demand for $\mathrm{P}$ fertilizer [34]. Among K levels increased stover yield (7660 $\mathrm{kg} \mathrm{ha}^{-1}$ ) was recorded where $\mathrm{K}$ was applied at the rate of $120 \mathrm{~kg} \mathrm{ha}^{-1}$ though statistically at par with $90 \mathrm{~kg} \mathrm{ha}^{-1}(7667 \mathrm{~kg}$ $\left.\mathrm{ha}^{-1}\right)$, while minimum stover yield $(6105 \mathrm{~kg}$ $\left.\mathrm{ha}^{-1}\right)$ was observed in control plots. Enhancement in stover yield with the increased $\mathrm{K}$ level might be attributed to the increase in the height of maize plants. The same results were reported by [30] that considerable increased in stover yield of maize with $\mathrm{K}$ application was recorded over the control plots. The interaction of $\mathrm{P}$ and $\mathrm{K}$ 
each applied at $120 \mathrm{~kg} \mathrm{ha}^{-1}$ resulted in higher stover yield of maize.

Harvest index (\%)

$\mathrm{P}$ and $\mathrm{K}$ levels significantly influenced harvest index of maize, whereas $\mathrm{P} \times \mathrm{K}$ interaction was non-significant (Table 1). In case of phosphorus levels increased harvest index $(37.6 \%)$ was recorded in plots where phosphorus was applied at the rate of $60 \mathrm{~kg}$ $\mathrm{ha}^{-1}$ which is statistical at par with $120 \mathrm{~kg} \mathrm{P}$ $\mathrm{ha}^{-1}(37.4 \%)$ and $90 \mathrm{~kg} \mathrm{P} \mathrm{ha}{ }^{-1}(37.4 \%)$ while, minimum harvest index $(34.0 \%)$ was recorded in control plots. The enhancement in harvest index with application of phosphorus levels might be due to the increased in yield and yield components of maize as found by [35] whereas, increase in harvest index $(38.2 \%)$ was recorded in those experimental units where potash was applied at the rate of $120 \mathrm{~kg} \mathrm{ha}^{-1}$ were statistically at par with those plots where potash was applied at the rate of $90 \mathrm{~kg} \mathrm{ha}^{-1}$ $(37.6 \%)$ and $60 \mathrm{~kg} \mathrm{ha}^{-1}(37.4 \%)$ whereas minimum harvest index $(33.1 \%)$ was recorded in control experimental units. The increase in harvest index with the increase in potash level might be due to more partitioning of assimilates toward sink. More harvest index was noted with higher potash applied [36]. In case of interaction between $\mathrm{P}$ and $\mathrm{K}$ increased harvest index was found with application of $60 \mathrm{~kg} \mathrm{P} \mathrm{ha}^{-1}$ and $120 \mathrm{~kg}$ $\mathrm{K} \mathrm{ha}^{-1}$ and no further increase in harvest index beyond the $60 \mathrm{~kg} \mathrm{P} \mathrm{ha}^{-1}$ was recorded. The same results were also reported by [20] who recorded that harvest index was significantly affected by PK fertilizer in different levels.

\section{Conclusion}

It is concluded that $\mathrm{P}$ at the rate of $120 \mathrm{~kg}$ $\mathrm{ha}^{-1}$ and $\mathrm{K}$ at the rate of $90 \mathrm{~kg} \mathrm{ha}^{-1}$ resulted in more rows ear ${ }^{-1}$, more grain row $^{-1}$, more grains ear ${ }^{-1}$, maximum 1000 grains weight, more biological and grain yield. Therefore,

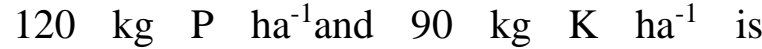
recommended for obtaining higher yield and yield component of maize under agro ecological conditions of Peshawar valley.

\section{Authors' contributions}

Conceived and designed the experiments: AA Khan, Inamullah, G Sadiq, A Rab \& H Fayyaz, Performed the experiments: G Sadiq, A Rab, H Nawaz \& WA Khattak, Analyzed the data: G Sadiq, AA Khan, H Raza, G Naz \& AA Khan, Contributed reagents/ materials/ analysis tools: J Amin, HA Khan, I Ali \& S Ali, Wrote the paper: G SA Ali Khan, A Rab, Inamullah \& H Raza.

\section{References}

1. Masood T, Rozina G, Fazal M, Fazal J, Zahid Hussain, Nadia N, Hamayoon K, Nasiruddin \& Hayatullah K (2011). Effect of different phosphorus levels on the yield and yield component of maize. Sarhad J. Agric 27(2):167-170.

2. Khodarahmpour Z (2011). Effect of drought stress induced by polyethylene glycol (PEG) on germination indices in corn (Zea mays L.) hybrids. African J Biotech 10 (79): 18222-18227.

3. MNFSR (2014). Ministry of National Food Security and Research, Agricultural Statistics, Economic Wing, Government of Pakistan, Islamabad. Available at: http://www.mnfsr.gov.pk.

4. Khan F, Khan S, Fahad S, Faisal S, Hussain S, Ali S \& Ali A (2014). Effect of different levels of nitrogen and phosphorus on the phenology and yield of maize varieties. Am J Plant Sci 5(17) 2582-2590.

http://dx.doi.org/10.4236/ajps.2014.5172 72.

5. Ayub M, Nadeem MA, Sharar MS \& Mahmood N (2002). Response of maize (Zea mays L.) fodder to different levels of nitrogen and phosphorus. Asian $J$ Plant Sci 1(4): 352-354.

6. Ali J, Bakht J, Shafi M, Khan S \& Shah WA (2002). Uptake of nitrogen as affected by various combinations of 
nitrogen and phosphorus. Asian J Plant Sci 1(4):367-369.

7. Qasim M, Himayrull H \& Subha M (2001). Effect of increasing levels of phosphorus and seed rate on the economic yield of maize. Online $J$ Biol Sci 1(1):40-42.

8. Reddya AR, Chaitanya KV \& Vivekanandand M (2004). Drought induced responses of photosynthesis and antioxidant metabolism in higher plants. J Plant Physiol 161: 1189-1202.

9. Hamza MA \& Anderson WK (2003). Response of soil properties and grain yields to deep ripping and gypsum application in a compacted loamy sand soil contrasted with a sandy clay loam soil in Western Australia. Aust J Agr Res 54:273-282.

10. Steel RGD, Torrie JH \& Dicky DA (1997). Principles and Procedures of Statistics, A Biometrical Approach. 3rd Ed. McGraw Hill, Inc. Book Co. N.Y. USA. pp. 352-358.

11. Younas M, Rehman H \& Hayder G (2002). Magnitude of variability for yield and associated traits in maize hybrids. Asian J Plant Sci 1(6): 694-696.

12. Minjian $\mathrm{C}$, Haiqui $\mathrm{Y}$, Hongkui $\mathrm{Y} \&$ Chungi J (2007). Difference in tolerance to potassium deficiency between maize inbred lines. Plant Prod Sci 10(1):42-46.

13. Akhtar M, Ahmad S, Mohsin S \& Mehmood T (1999). Interactive effect of phosphorous and potassium nutrition on the growth and yield of hybrid maize. Pak J Biolo Sci 2 (1): 240-241.

14. Ali A, Hussain M, Habib HS, Kiani TT, Anees MA \& Rahman MA (2016). Foliar spray surpasses soil application of potassium for maize production under rainfed conditions. Turk J Field Crops 21(1): 36-32.

15. Frootan A \& Yarnia M (2015). Effects of Soil and Foliar Applications of potassium sulfate on yield and yield components of maize SC. 704 under different irrigations levels in Iran. $A d v$ Environ Biol 9(4): 382-38.

16. Tariq M, Saeed A, Nisar M, Mian IA, \& Afzal M (2011). Effect of potassium rates and sources on the growth performance and on chloride accumulation of maize in two different textured soils of Haripur, Hazara Division. Sarhad J Agric 27 (3): 416422.

17. Masood T, Gul R, Munsif F, Jalal F, Hussain Z, Noreen N, Khan H, Uddin N \& Khan H (2011). Effect of different phosphorus levels on the yield and yield components of maize. Sarhad J Agric 27(2): 167-170.

18. Oktem AG \& Oktem A (2005). Effect of nitrogen and intra spaces on sweet corn ear characteristics. Asian J Plant Sci 4(4): 361-364.

19. Rasheed M, Bhutta WM, Anwar-Ul Haq M \& Ghaffar A (2004). Genotypic response of maize hybrids to NP applications. Intl J Agric Biolo 6(4): 721-722.

20. Sharar MS, Ayub M, Nadeem MA \& Ahmad N (2003). Effect of different rates of nitrogen and phosphorus on growth and grain yield of maize. Asian Plant Sci 2(3): 347-349.

21. Chaudhry A \& Malik JK (2000). Determination of optimum level of potash and its effect on yield and quality of maize. Pak J Bio Sci. 3(12): 75-80.

22. Sadiq SA \& Jan A (2001). Effect of graded application of potash on kharif maize sown at different fertility levels. M.Sc (Hons) Thesis, Deptt. Agron. NWFP Agric. Uni. Peshawar.

23. Haq IU, Zamir SI, Javed A \& Hussain S (2014). Sustainable phosphorous management in maize (Zea mays L.) through seed inoculation with PSM (Phosphorous Solubilizer 
Microorganisms). Intl J Agri Crop Sci 7(10): 769-773.

24. Akhtar ME, Saleem MT \& Stauffer MD (2003). Potassium in Pakistan Agriculture. Pakistan Agric. Research Council, Islamabad.

25. Hussain N, Khan AZ, Akbar H \& Akhtar $S$ (2006). Growth factors and yield of maize as influenced by phosphorus and potash fertilization. Sarhad J Agric 22(4): 579-583.

26. Tababtabaei SA \& Ranjbar GH (2012). Effect of different levels of nitrogen and potassium on grain yield and protein of triticale. Int Res $J$ of Applied and Basic Sci 3(2): 390-393.

27. Hanif M (1990). Growth and yield of maize genotypes as influenced by PK application. M.Sc (Hons) Agronomy Thesis, Deptt. Of Agronomy, Univ. of agri. Faisalabad.

28. Ahmad M, Hussain N, Jan A, Ahmad K \& Hussain S (2007). Response of maize to phosphorus levels and plant density. Sarhad J Agric 23(1): 69-74.

29. Saleem A, Javed HI, Saleem R, Ansar M \& Zia MA (2011). Effect of split application of potash fertilizer on maize and sorghum in Pakistan. Pakistan $J$ Agric Res 24(1-4):31-34.

30. Ravindra VM, Math KK, Ramya SH, Prashanth KM \& Hosmath JA (2016). Distillery spent wash as a potassium source on yield attributes, yield and economics of maize. Int J Agri Sci 8(18): 1318-1321.

31. Staffer MD, Akhtar ME \& Saleem MT (1995). Potassium Research and Development in Pakistan. Status Report. Pak Agri Res Council, IslamabadPakistan.

32. Kogbe JOS \& Adediran JA (2003). Influence of $\mathrm{N}, \mathrm{P}$ and $\mathrm{K}$ application on yield of maize in Savana Zone of Nigeria. African J Biotech 2(10): 345349.

33. Maqsood M, Abid AM, Iqbal A \& Hussain MI (2001). Effect of variable rate of nitrogen and phosphorus on growth and yield of maize (golden). Online J Biol Sci 1(1): 19-20.

34. Hussain MZ \& Haq IU (2000). P sorption capacities of KPK soils. In: Proceedings of maize phenology, yield and profitability in Northwest Pakistan. Int J Plant Prod 4: 281-292.

35. Amanullah, Zakirullah M \& Khalil SK (2010). Timing and rate of $\mathrm{P}$ application influence maize phenology, yield and profitability in Northwest Pakistan. Int $J$ Plant Prod 4(4): 281-292.

36. Laghari GM, Oad FC, Tunio S, Gandahi AW, Siddique MH, Jagirani AW \& Oad SM (2010). Growth, yield and nutrient uptake of various wheat cultivars under different fertilizer regimes. Sarhad J Agric 26(4): 491-497. 